\title{
Matematik Öğretmenlerinin Rasyonel Sayılar Konusunda Öğrencilerin Yaşadıkları Öğrenme Güçlüklerine Sundukları Öneriler ${ }^{a}$
}

\author{
Muhammet Doruk ${ }^{\mathrm{b}, \mathrm{c}}$
}

Özet

$\mathrm{Bu}$ çalışmanın amacı matematik öğretmenlerinin rasyonel sayılar konusunda öğrencilerin yaşadıkları yaygın öğrenme güçlüklerine sundukları çözüm önerilerini ortaya çıkarmaktır. Çalışmada nitel araştırma yaklaşımı benimsenmiştir. Çalışma, bir durum çalışması örneğidir. Çalışmanın katılımcılarını 2017-2018 eğitim öğretim yılında Türkiye'nin Doğu Anadolu Bölgesi'ndeki devlet ortaokullarında görev yapan altı matematik öğretmeni oluşturmaktadır. Öğretmenler belirlenirken amaçlı örnekleme yöntemlerinden maksimum çeşitlilik örnekleme yöntemi kullanılmıştır. Araştırmanın verileri araştırmacı tarafından geliştirilen yarı yapılandırılmış görüşme formu yardımıyla toplanmıştır. Görüşmelerde öğretmenlere sırasıyla rasyonel sayılarda sıralama, toplama, çarpma ve bölme konularında literatürde tespit edilen örnek öğrenci güçlükleri sunulmuştur. Öğretmenlerden öncelikle kendilerine sunulan öğrenci çözümünde yer alan öğrenme güçlügünü incelemeleri ve sınıflarında bu tür öğrenme güçlügüne sahip öğrencileri olduğunda, söz konusu öğrenme güçlüğünü ortadan kaldırmak için nasıl bir öğretim uygulayacaklarını belirtmeleri istenmiştir. Görüşmelerden elde edilen veriler içerik analizi yardımıyla çözümlenmiştir. Çalışma sonucunda öğretmenlerin çoğunlukla yapılandırmacı yaklaşıma uygun olmayan kural hatırlatmayı önerdikleri ortaya çıkmıştır.
Anahtar Kelimeler

Rasyonel Sayılar

Öğrenme Güçlüğü

Matematik Öğretmeni

Matematik Eğitimi

Makale Hakkında

Geliş Tarihi: 26.10.2019

Kabul Tarihi: 09.05.2020

Doi: $10.18026 /$ cbayarsos.638607

\section{The Suggestions of Mathematics Teachers Regarding Students' Learning Difficulties in Rational Numbers}

\begin{abstract}
The aim of this study is to reveal mathematics teachers' suggestions regarding the learning difficulties of students in rational numbers. This is an example of a case study, which is a qualitative research approach. The participants of the study consisted of six mathematics teachers in state middle schools during the 2017-2018 academic year in Eastern Anatolia Region of Turkey. The maximum variation sampling method, one of the purposeful sampling methods, was used in determining the teachers. The data of the study was collected with a semistructured interview form developed by the researcher. In the interviews, samples of student difficulties identified in the literature on ordering, addition, multiplication and division of rational numbers were introduced to the teachers respectively. The teachers were first asked to examine the learning difficulties. Teachers were asked to indicate how they would implement instruction to eliminate such learning difficulties when they have students with such learning difficulties in their classrooms. The data obtained from the interviews were analyzed through the content analysis. As a result of the study, it was revealed that the teachers mostly suggested the rule reminder method which was not suitable for the constructivist approach.
\end{abstract}

Keywords

Rational Numbers

Learning Difficulty

Mathematics Teachers

Mathematics Education

About Article

Received: 26.10.2019

Accepted: 09.05.2020

Doi: 10.18026/cbayarsos.638607

\footnotetext{
a Bu çalışma 5. Uluslararası Çağdaş Eğitim Araştırmaları Kongresi'nde (Frankfurt-Almanya) sözlü bildiri olarak sunulmuştur.

b İletişim Yazarı: mdoruk20@gmail.com

c Dr. Öğretim Üyesi, Hakkâri Üniversitesi/HAKKARİ, ORCID ID: 0000-0003-3085-1706
} 


\section{Giriş}

Kesirler; rasyonel sayılar, ondalık sayılar, oran, orantı ve ölçüler gibi birçok konunun temeli olan bir kavramdır (İpek, Işık \& Albayrak, 2005; Vanhille \& Baroody, 2002). Bir kesir, tam olmayan miktarları göstermek için kullanılan sayılardır (Olkun \& Toluk Uçar, 2009). Bir bütünün eş parçalarından her biri veya birkaçına verilen isimdir (Baykul, 2014). Kesir sayısı ise muhtelif bütünlerin aynı çoklukta parçalarının oluşturduğu kümenin ortak özelliği olup (Altun, 2013) bir bütünü oluşturan eşit parçaların miktarını belirlemek için ortaya çıkan bir kavramdır (Pesen, 2008). Kesir kavramı ilkokul öğrencilerine; birinci sınıfta bütün ve yarım, ikinci sınıfta bütün, yarım ve çeyrek, üçüncü sınıfta kesir, pay, payda, kesir çizgisi ve birim kesir, dördüncü sınıfta basit kesir, bileşik kesir, tam sayılı kesir ve kesirlerde toplama ve çıkarma işlemleri kavramlarıyla tanıtılmaktadır (Millî Eğitim Bakanlığı [MEB], 2018). Kesir kavramı ile öğrenciler ortaokulda ilk defa beşinci sınıf matematik ders programında doğal sayılar konusunun öğretiminden hemen sonra karşılaşmaktadırlar (MEB, 2018). Buna göre ortaokul seviyesinde öğrencilerinin karşılaştıkları ilk soyut kavramın kesirler olduğu söylenebilir.

Ersoy ve Erbaş (2005), öğrencilerin matematik öğrenmede yaşadıkları güçlüklerin doğal sayılar kavramından sonra öğretimi yapılan kesir kavramı olduğunu ve bu kavramda yaşanılan güçlüklerin ilerideki matematik öğrenmelerini olumsuz etkilediğini belirtmiştir. Buna göre kesirler ve onunla bağlantılı olan rasyonel sayılar konusunun öğretiminin, matematiğin diğer kavramlarını öğrenme adına hayati bir önem taşıdığı söylenebilir. Özellikle kesirler, ilköğretim matematiğinde önemlidir ve kendinden sonra gelen kavramların öğrenilmesine olanak sağlar (Son, 2011). Rasyonel sayılar ile ilgili edinilen bilgiler, öğrencilerin günlük hayatta karşılaştıkları problemin üstesinden gelmelerine ve öğrendikleri bilgileri anlamlandırma yeteneklerine yardımcı olmaktadır (Prediger, 2011). Buna karşın öğrencilerin anlamlı matematik öğreniminde büyük bir öneme sahip olan rasyonel sayılarda yaşadıkları güçlükler, gelecekteki matematik öğrenme süreçlerini olumsuz etkileyecektir (Brown \& Quinn, 2007; Wu, 2001)

Ortaokul matematik ders programı ve kaynak kitaplar incelendiğinde (Bektaş, Kahraman \& Temel, 2018; Böge \& Akıllı, 2018; Cırıtçı, Gönen, Kavas, Özarslan, Pekcan \& Şahin, 2018; Erenkuş \& Eren Savaşkan, 2018; MEB, 2018), ortaokul beşinci ve altıncı sınıfta kesir konusunun öğretiminin yapıldığı, yedinci sınıfta ise bu konunun rasyonel sayılar adıyla genişletildiği görülmüştür. Programda benzer özellikler taşımalarına rağmen sınıf seviyesine göre alt öğrenme alanının isminin değişimi, kesir ile rasyonel sayı kavramları arasındaki farkın ne olduğunu düşündürmüştür. Ortaokul seviyesinde rasyonel sayılar genel olarak: a ve b birer tam sayı, b sıfırdan farklı olmak üzere, a/b biçimindeki sayılar olarak tanımlanır (Baykul, 2014; Erenkuş \& Eren Savaşkan, 2018; Vamvakoussi \& Vosniadou, 2010). Özellikle üniversite düzeyindeki kaynaklarda sunulan rasyonel sayı tanımlarında, yukarıdaki tanıma ek olarak a ile b sayılarının aralarında asal olmasının yani bir ve kendisi dışında ortak pozitif böleni olmamasının gerekliliği ifade edilmiştir (Balcı, 2013; Çelik, 2006). Birçok kaynakta aralarında asal olma şartı açıkça belirtilmemesine rağmen (Yanık, 2013) irrasyonel sayıların rasyonel sayı olmadıklarının ispatlarında kilit özellik olarak kullanılmıştır (Balcı, 2013). Ortaokul ve üniversite düzeyinde sunulan tanımlara göre, rasyonel sayılar negatif veya pozitif değerler alabileceği gibi sıfır değerini de alabilir. Buna göre rasyonel sayıların üniversite seviyesinde kullanılan tanımı dikkate alındığında bir rasyonel sayı tek bir değere sahipken; ortaokul 
seviyesinde kullanılan rasyonel sayılar tanımı dikkate alındığında ise bir rasyonel sayıya denk olan sonsuz çoklukta rasyonel sayılar yazılabilir.

Bazı kaynaklarda kesir kavramının a/b (b sıfırdan farkı) şeklindeki iki tam sayının oranı olduğu, kesirler arasından pay ve paydası aralarında asal olanlarının ise rasyonel sayılar olduğu belirtilmiştir (Çelik, 2006). Bu düşünceye göre kesirler ile rasyonel sayılar arasındaki tek fark birbirine bölünen iki tam sayının aralarında asal olup olmamasıdır. Bu düşüncelere karşın bir kesrin iki doğal sayının, rasyonel sayının ise iki tam sayının birbirine oranı olduğunu düşünen matematik eğitimcileri de vardır (Alacacı, 2014; Baykul, 2002; Lamon, 2007; Olkun \& Toluk Uçar, 2009). Gerçekten de ortaokul matematik dersleri için sunulan kaynak kitaplar incelendiğinde (Bektaş, Kahraman \& Temel, 2018; Cırıtçı ve diğerleri, 2018; Erenkuş \& Eren Savaşkan, 2018;), kesir kavramı, parça-bütün ilişkisine dayalı olarak, iki doğal sayının oranı şeklinde kullanılmıştır. Rasyonel sayılar ise iki tam sayının oranı olarak ele alınmış ve aralarında asallık şartına değinilmemiştir.

Kesirler ile rasyonel sayılar arasındaki ilişkiye değinen araştırmacılar farklı özelliklere vurgu yapmışlardır. Usiskin (1979) kesirlerin bir sayı sisteminin parçası olmadığını belirtmiştir. Kesirler a/b şeklinde yazılan ve negatif değer almayan ifadelerdir (Erdem, 2016). Matematik eğitimcileri çoğunlukla bir rasyonel sayının tek bir şekilde yazılabildiğini, bir rasyonel sayıya denk olan sonsuz sayıda kesrin yazılabildiğini belirtmişlerdir (Lamon, 2007; Stafylidou,\& Vosniadou, 2004; Vamvakoussi \& Vosniadou, 2010). Bu ilişkiyi matematiksel olarak, sonsuz denklik sınıflarından oluşan kümeye rasyonel sayılar kümesi, her bir denklik sınıfının elemanlarının ise kesir olduğunu ifade etmişlerdir (Behr, Harel, Post \& Lesh, 1992; Ni, 2001). Niven (1961) kesir kavramının tek başına pay ve paydadan oluşan bir nümerik gösterimden ibaret olduğunu ve bir kesrin sonsuz farklı sayıda gösteriminin olacağını belirtmiştir. Rasyonel sayıların ise sadece pay/payda şeklindeki gösterim kalıplarıyla ifade edilmesinin mümkün olmadığını vurgulamıştır. Lamon (2007) her kesre karşılık yalnızca bir rasyonel sayının karşılık geldiğini ancak her rasyonel sayının ise bir kesir olarak ifade edilemeyeceğine dikkat çekmiştir.

Ortaokulda matematik dersi öğretim programında kesir kavramının doğal sayılar dikkate alınarak sunulması eğitimsel ilkelerin bir gereği olarak düşünülebilir. Beşinci sınıf öğrencilerine kesirler konusunun öğretimi doğal sayılar konusunun öğretiminden sonra yapılmaktadır. Öğrencilerin ortaokulda ilk defa karşılaşacakları kesir kavramının anlaşılması için önceki öğrenmeleri ile ilişkilendirilerek sunulması makul bir durum olarak düşünülebilir. Olive (1999) de rasyonel sayı teriminin formal matematiksel tanıma atıfta bulunduğunu, kesir kavramının ise ilkokul matematiğine hitap ettiğini belirtmiştir. Bu çalışmada da kesir ve rasyonel sayılar kavramları uygulanan ortaokul matematik dersi öğretim programında yer aldığı şekliyle değerlendirilmiştir. Bu çalışmada isim olarak kesir yerine rasyonel sayı terimi kullanılmıştır. Bunun sebebi hem rasyonel sayılar kümesinin kesir sayılarını da kapsaması hem de çalışmaya katılan öğretmenlerin yedinci sınıf matematik dersi öğretiminden sorumlu olmalarıdır. Bilindiği gibi ortaokul matematik dersi öğretim programında, ilgili konunun öğretimi rasyonel sayılar başlı̆̆ı altında yapılmaktadır.

Rasyonel sayılar semantik olarak birden çok özelliği bulunan ve çoklu temsil edilebilme bakımından zengin kavramlardan biridir. Rasyonel sayılarda tanımlanan işlemler doğal sayılar ve tam sayılarda tanımlanan işlemlerden hem işlemsel hem de kavramsal olarak farklı özellikler taşımaktadır. Rasyonel sayılar genel olarak parça-bütün ilişkisi, bölüm, oran, işlemci ve ölçme anlamlarına gelebilmektedir (Alacac1, 2014; Toluk, 2002; Van de Walle, Karp \& Bay 
Williams, 2013). Rasyonel sayıları göstermek için ise çoğunlukla hacim, bölge veya alan, çizgi veya uzunluk ve küme modelleri kullanılmaktadır (Alacacı, 2014; Altun, 2013; Olkun \& Toluk Uçar, 2009; Van de Walle ve diğerleri, 2013 ).

Ortaokul öğrencileri ile yapılan araştırmalarda, öğrencilerin rasyonel sayıları kavramsal olarak anlamakta güçlük yaşadıkları ve birçok güçlüğe sahip oldukları ortaya çıkmıştır (Birgin \& Gürbüz, 2009; de Castro, 2008; Işık \& Kar, 2012; Macit \& Nacar, 2019; Soylu \& Soylu, 2005; Stafylidou \& Vosniadou, 2004; Tirosh, 2000; Ünlü \& Ertekin, 2012). Bu çalışmalarda öğrencilerin özellikle rasyonel sayılarda dört işlem yapma (Biber, Tuna \& Aktaş, 2013; Birgin \& Gürbüz, 2009; Kocaoğlu \& Yenilmez, 2010; Soylu \& Soylu, 2005; Şiap \& Duru, 2004; Yeniterzi, 2009) ve rasyonel sayıları sıralama (Biber, Tuna \& Aktaş, 2013; Stafylidou \& Vosniadou, 2004; Zengin, 2013) konusunda güçlük yaşadıkları belirlenmiştir. Ortaokul öğrencilerinin toplama işlemi yaparken pay ve paydayı doğrudan toplamaları (Soylu \& Soylu, 2005), toplama işlemi kuralını çarpma işlemine uyarlamaları (Kocaoğlu \& Yenilmez, 2010), bölme işlemini hem işlemsel hem de kavramsal olarak anlayamamaları (Durmuş, 2005), kesirleri sıralarken sadece pay veya paydanın büyüklügüne göre sıralama yapmaları (Biber, Tuna \& Aktaş, 2013) en sık karşılaşılan güçlükler arasında yer almaktadır.

Öğrencilerin yaşadıkları güçlüklerin kaynaklarının; öğrencilerin rasyonel sayıları bir sayı olarak algılayamamaları, o zamana kadar doğal sayılara alışmış öğrencilerin tam olmayan sayıları anlamakta güçlük yaşamaları, öğrencilerin tam sayılarda yaptıkları işlemleri rasyonel sayılara genellemeleri, rasyonel sayıların birçok anlama sahip olması ve birden çok gösterimle temsil edilebilmesi, rasyonel sayılarla ilgili temel kavramların öğrencilerin zihinlerinde oluşmadan sembolik gösterim ve kurallara geçiş yapmada aceleci davranılması, parça-bütün ilişkisi anlamının gereğinden çok vurgulanması olduğu belirtilmiştir (Alacacı, 2014; Bezuk \& Bieck, 1993; Haser \& Ubuz, 2001; Olkun \& Toluk Uçar, 2009; Şiap \& Duru, 2004; Van de Walle ve diğerleri, 2013). Bazı araştırmacılar da kesir konusunun öğretimi ve öğreniminde yapılan yanlışlıkların, yaşanılan güçlüklerin kaynağı olduğunu vurgulamıştır. Çalışmalarda; kesir kavramının tamamıyla öğrenilmesine yeterli zaman ayırmadan ve öğrenciler gerekli alt yapıya sahip olmadan kesirlerde işlemlere geçilmesi (Mok, Cai \& Fong-Fung, 2008; Orhun, 2007), kavramsal anlamaya yeterince yer verilmemesi (Pantziara \& Philippou, 2011) ve prosedürlerin öğrencilere ezbere öğretilmesi (Kılcan, 2006; Tirosh, 2000) öğrenci güçlüklerin sebebi olarak belirtilmiştir. Öğrencilerin yaşadıkları güçlüklerin üstesinden gelebilmek için öğretim sırasında gerçek yaşam durumlarından yararlanılması, somut modellerin ve görsel materyallerin kullanılması, ezbere dayalı öğretim yerine sezgi kaynaklı kavramsal anlayışı sağlayacak öğrenme ortamlarının oluşturulması, rasyonel sayıların tüm anlamlarının ve temsillerin öğrencilere sunulması, çağdaş öğretim yöntemlerinin kullanılması önerilmiştir (Albayrak, 2010; Demirdöğen \& Kaçar, 2010; Doğan-Temur, 2011; Güç, 2017; Durmuş, 2005; Işık, 2011; İpek ve diğerleri., 2005; Tirosh, 2002; Toluk, 2002; Tutak, 2019).

Öğrencilerin yaşadıkları güçlüklere paralel olarak, yapılan araştırmalarda matematik öğretmeni adayı ve matematik öğretmenlerinin rasyonel sayılar konusunda yeterli kavramsal anlayışa sahip olmadıkları ve birçok güçlüğe sahip oldukları tespit edilmiştir (Can, 2019; Erdem, 2016; Gökkurt, Şahin \& Soylu, 2012; Iş1k, 2011; Karaağaç \& Köse, 2015; Lo \& Luo, 2012). Matematik öğretmeni adayı ve matematik öğretmenlerinin öğrencilerin yaşadıkları güçlüklere yönelik sundukları öğretim yöntemlerini konu edinen araştırmaların ise sınırlı sayıda olduğu tespit edilmiştir (Can, 2019; Eroğlu, 2012; Kılcan, 2006; Mumcu, 2017). Matematik öğretmenleri ile yapılan bazı çalışmalarda öğretmenlerin kesirlerde bölme işlemi ile ilgili bilgileri (Kılcan, 
2006;), kesirlerde işlemler konusuna ilişkin zorluk ve kavram yanılgıları ile ilgili pedagojik alan bilgileri (Can, 2019) ve kesirlerin öğretiminde kullanılan etkinliklere ilişkin görüşleri alınmıştır (Gökkurt, Soylu \& Demir, 2015).

Öğrencilerin rasyonel sayılar konusunda yaşadıkları güçlüklerin üstesinden gelebilmesi için öğretim sürecinde matematik öğretmenlerine önemli görevler düşmektedir. Öğrencileri süreç içerisinde yakından takip eden, muhtemel güçlüklerin farkında olan ve öğrencilerinin olası güçlüklerine çözüm önerileri geliştirebilen öğretmenlerin öğretim sürecinde daha başarılı olacağ1 söylenebilir. Çünkü öğrencilerin öğretilen kavramla ilgili sahip olabilecekleri güçlüklerin farkında olmak ve bu güçlüklerin nasıl üstesinden gelinebileceği konusunda bilgili olmak bir öğretmenin sahip olması gereken en önemli pedagojik becerileri arasındadır (Shulman, 1986). Ayrıca matematik öğretmenlerinin kesirler konusunda öğrencilerin yaşadıkları güçlüklere sundukları öğretimsel öneriler üzerine yapılan çalışmaların azlığı, bu çalışmadan elde edilen sonuçları değerli kılacaktır. Bu nedenle çalışmada, matematik öğretmenlerinin rasyonel sayılar konusunda yaşanılan örnek öğrenci güçlüklerine sundukları çözüm önerilerini ortaya çıkarmak amaçlanmıştır. Bu amaca ulaşmak için aşağıdaki araştırma sorularının yanıtları aranmıştır.

a. Matematik öğretmenleri rasyonel sayılarda sıralama konusunda yaşanılan örnek öğrenme güçlüklerine ne tür çözüm önerileri sunmaktadır?

b. Matematik öğretmenleri rasyonel sayılarda toplama konusunda yaşanılan örnek öğrenme güçlüklerine ne tür öneriler sunmaktadır?

c. Matematik öğretmenleri rasyonel sayılarda çarpma işlemi konusunda yaşanılan örnek öğrenme güçlüklerine ne tür çözüm önerileri sunmaktadır?

d. Matematik öğretmenleri rasyonel sayılarda bölme konusunda yaşanılan örnek öğrenme güçlüklerine ne tür çözüm önerileri sunmaktadır?

\section{Yöntem}

\section{Araştırma Modeli}

Bir durum çalışması örneği olarak bu çalışmada nitel araştırma yaklaşımı benimsenmiştir. Nitel araştırmalar algıların ve olayların doğal ortamda gerçekçi ve bütüncül olarak ortaya çıkarılması için nitel bir sürecin takip edildiği çalışmalardır (Yıldırım \& Şimşek, 2011). Durum çalışmalarında, araştırılmak istenen durum ya da olaylar kendi sınırlılığ olarak betimlenir (Kaleli Yılmaz, 2015; Merriam, 2013). Bu çalışmada da matematik öğretmenlerinin öğrenci güçlüklerine yönelik öğretimsel önerileri rasyonel sayılarda işlemler ve sıralama konusu ile sınırlandırarak ortaya çıkarılmaya çalışılmıştır.

\section{Araştırma Grubu}

Çalışmanın araştırma grubunu, 2017-2018 eğitim öğretim yılında Türkiye'nin Doğu Anadolu Bölgesi'ndeki devlet ortaokullarında görev yapan altı matematik öğretmeni oluşturmaktadır. Öğretmenler belirlenirken amaçlı örnekleme yöntemlerinden maksimum çeşitlilik örnekleme yöntemi kullanılmıştır. Çalışma için ortaokul matematik öğretmenleri meslekteki deneyimlerine göre üç gruba ayrılmıştır. Her gruptan iki öğretmen seçilerek toplamda altı ortaokul matematik öğretmeni ile çalışma yürütülmüştür. Maksimum çeşitlilik örnekleme yönteminin tercih edilmesinin sebebi ise farklı öğretim deneyimlerine sahip öğretmenlerin bakış açılarından yararlanarak araştırma problemlerinin farklı yansımalarını ortaya 
çıkarmaktır. Öğretmenler yedinci sınıf öğrencileri ile 2017-2018 eğitim öğretim yılında rasyonel sayılar konusunun öğretimini tamamlamışlardır. Öğretmenlerin gerçek isimleri yerine takma isimler kullanılmıştır. Tablo 1'de çalışmaya katılan öğretmenlerin mesleki deneyimlerine yönelik bilgiler sunulmuştur.

Tablo 1. Öğretmenlerin Mesleki Deneyim Süreleri

\begin{tabular}{cccc}
\hline Öğretmenler & $0-5$ yıl & $5-10$ yıl & 10 yil ve üzeri \\
\hline Ayşe & $\vdots$ & & \\
Gözde & & \\
Yücel & & \\
Fatoş & & & \\
Mahmut & & \\
Ali & & \\
\hline
\end{tabular}

\section{Veri Toplama Süreci}

Araştırmanın verileri, araştırmacı tarafından geliştirilen etkinlik temelli yarı yapılandırılmış görüşme formu yardımıyla toplanmıştır. Görüşmeler, öğretmenlerin görev yaptığı okullarda, öğretmenlerin çevresel faktörlerden etkilenmeyeceği bir ortamda bireysel olarak gerçekleşmiştir. Görüşmeler ses kayıt cihazı kullanılarak kayıt altına alınmıştır. Öğretmenlere görüşmelerde sırasıyla rasyonel sayılarda sıralama, toplama, çarpma ve bölme konularında, Birgin ve Gürbüz, (2009) ile Soylu ve Soylu'nun (2005) çalışmalarında tespit ettikleri öğrenci hataları sunulmuştur. Öğretmenlerden öncelikle kendilerine sunulan öğrenci çözümünde yer alan öğrenme güçlüğünü incelemeleri istenmiştir. Öğretmenlere her bir güçlük için "Sınıfınızda bu öğrenme güçlügüne sahip olan bir öğrenci olsaydı, bu güçlüğün üstesinden gelmek için ne tür bir yöntem uygulardınız?" sorusu sorulmuştur. Öğretmenlerin çözüm önerileri alınmış ve ses kayıt cihazı ile kayıt altına alınmıştır. Görüşmeler 30-40 dakika aralığında tamamlanmıştır.

\section{Verilerin Analizi}

Veri analizine hazırlık için görüşmelerin ses kayıtları transkript edilmiştir. Görüşmelerden elde edilen veriler içerik analizi yardımıyla çözümlenmiştir. Veri toplama aracının geçerliği ve veri analizinin güvenirliği için matematik eğitimi anabilim dalında doktorasını tamamlayan bir uzman ortaokul matematik öğretmeninin görüşleri alınmıştır. Uzman öğretmen veri toplama aracının çalışma için uygun olduğunu belirtmiştir. Çalışmada veri analizlerinin güvenirliği için araştırmacı ile uzman arasında uyuşum yüzdesi hesaplanmıştır. Tablo 3, Tablo 4, Tablo 5 ve Tablo 6 ' da sunulan kategoriler için hesaplanan uyuşum yüzdeleri sırasılyla, .88, $.100, .88, .83$ olarak belirlenmiştir. Çalışmadaki tüm kategoriler için uyuşum yüzdesi \%90 olarak tespit edilmiştir. Elde edilen bu değerler Miles ve Huberman'a (1994) göre \%70'in üzerinde bir değer olduğu için, veri analizinin güvenilir olduğu sonucuna ulaşılmıştır. Uyuşma sağlanamayan \%10'luk bölüm için uzmanla bir araya gelinmiş ve fikir birliğine varılmıştır. Uzmanla yapılan görüşme sonucunda "Görsel modeller" kategorisinin ismi "Model kullanma", "Tekrar" kategorisinin ismi "Uygulamalı tekrar", "İşlemleri farlı dönemlerde anlatma" kategorisinin ismi "Konu zamanlamasında değişiklik" ve "tekerlemeoyun-şarkı" kategorisinin ismi de "Farklı öğretim yöntemi" olarak düzenlenmiştir. Veri analizi sonucunda elde edilen kategorilerde bazı öğretmenler sadece bir kategoriye yönelik 
öneriler verirken, bazı öğretmenler de birden fazla kategoriye dahil olabilecek öneriler sunmuşlardır.

Çalışmada kullanılan rasyonel sayılarda sıralama konusunda yaşanılan güçlüklerde, öğrenciler rasyonel sayıların pay ya da paydasındaki sayıların büyüklüklerini dikkate alarak sıralama yapmaktadırlar. Rasyonel sayılarda toplama işleminde kullanılan güçlüklerde, öğrencilerin doğal sayılardaki toplama işleminin bir genellemesini yapmışlar ve pay ve paydayı kendi aralarında doğrudan toplamışlardır. Çarpma işlemi için sunulan öğrenci güçlüklerinde çarpma işleminin kuralı doğru olarak uygulanamamış, toplama işlemi kuralı çarpma işlemine uyarlanmaya çalışılmıştır. Bölme işlemi için kullanılan güçlüklerde öğrencilerin bölme işlemi için verilen kuralı yanlış uygulamışlardır. Çalışmada kullanılan bu güçlük çeşitleri matematik eğitimcileri tarafından belirtilen kesirler konusunda görülen en yaygın güçlükler arasında yer almaktadır (Alacacı, 2014; Baykul, 2014; Biber, Tuna \& Aktaş, 2013; Durmuş, 2005; Kocaoğlu \& Yenilmez, 2010; Olkun \&Toluk Uçar, 2009; Van de Walle ve diğerleri, 2013;). Tablo 2'de görüşmelerde kullanılan öğrenme güçlükleri ve özellikleri sunulmuştur.

Tablo 2. Görüşmelerde Kullanılan Öğrenme Güçlükleri ve Özellikleri

\begin{tabular}{|c|c|c|}
\hline Örnekler & Öğrenci gerekçesi & Öğrenci ifadesi \\
\hline $\begin{array}{l}\text { Örnek 1: 13/12, 4/3, } 7 / 6 \\
\text { kesirlerinin büyükten } \\
\text { küçüğe doğru sıralanış1 } \\
\text { aşağıdakilerden } \\
\text { hangisidir? (Soylu \& } \\
\text { Soylu, 2005) }\end{array}$ & \begin{tabular}{lr}
\multicolumn{2}{l}{ Rasyonel sayıların sadece } \\
payı dikkate & alınarak \\
paydaki & sayıların \\
büyüklügüune & göre \\
sıralama yapılmıştır.
\end{tabular} & 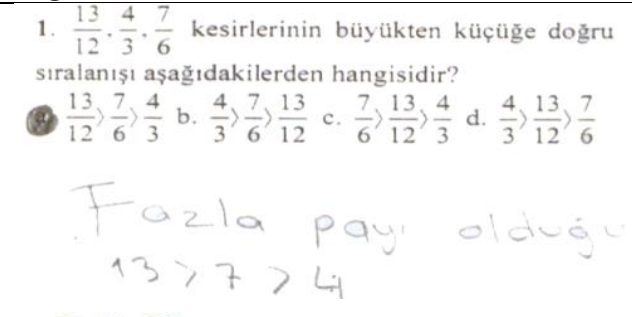 \\
\hline $\begin{array}{l}\text { Örnek 2: 7/4, 14/15, 28/22 } \\
\text { kesirlerinin büyükten } \\
\text { küçüğe doğru sıralanış1 } \\
\text { aşağıdakilerden } \\
\text { hangisidir? (Soylu \& } \\
\text { Soylu, 2005) }\end{array}$ & $\begin{array}{l}\text { Rasyonel sayıların sadece } \\
\text { paydası dikkate } \\
\text { paydadakirak } \\
\text { büyüklüğüner sayıların } \\
\text { sıralama yapılmıştır. }\end{array}$ & $\begin{array}{l}\frac{7}{4}, \frac{14}{15}, \frac{28}{22} \text { kesirlerinin büyükten küçüğe doğru } \\
\text { sıralanıș aşağıdakilerden hangisidir? } \\
\text { a. } \frac{14}{15} ; \frac{28}{22}>\frac{7}{4} \text { b }, \frac{14}{15}>\frac{7}{4}>\frac{28}{22}, \frac{28}{22}>\frac{14}{15}>\frac{7}{4} \text { d. } \frac{7}{4}>\frac{28}{22}>\frac{14}{15} \\
\text { Pay da daha fazla } \\
\text { olduḡu isin. }\end{array}$ \\
\hline $\begin{array}{l}\text { Örnek 3: 3/8+4/10 } \\
\text { işleminin sonucu } \\
\text { aşağ1dakilerden } \\
\text { hangisidir? (Soylu \& } \\
\text { Soylu, 2005) }\end{array}$ & $\begin{array}{l}\text { Pay ve payda ayrı iki sayı } \\
\text { olarak düşünülerek } \\
\text { paylar ve paydalar kendi } \\
\text { aralarında toplanmıştır. }\end{array}$ & 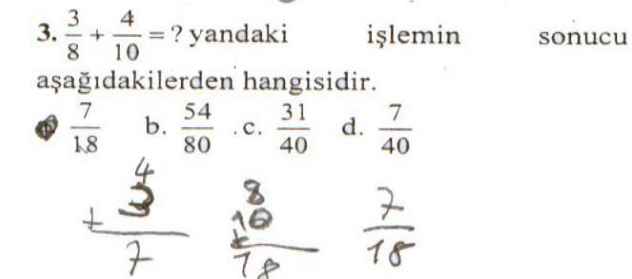 \\
\hline $\begin{array}{l}\text { Örnek 4: 7/9+4/9 } \\
\text { işleminin sonucu } \\
\text { aşağ1dakilerden } \\
\text { hangisidir? (Soylu \& } \\
\text { Soylu, 2005) }\end{array}$ & $\begin{array}{l}\text { Paydaları eşit olan } \\
\text { rasyonel sayılarda da pay } \\
\text { ve payda kendi aralarında } \\
\text { toplanmıştır. }\end{array}$ & 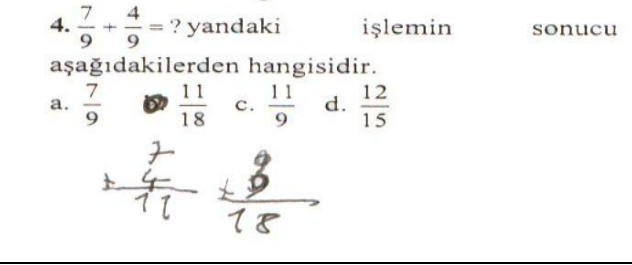 \\
\hline
\end{tabular}




\begin{tabular}{|c|c|c|}
\hline $\begin{array}{l}\text { Örnek 5: 4/7x3/7 } \\
\text { işleminin sonucu } \\
\text { aşağ } 1 \text { dakilerden } \\
\text { hangisidir? (Soylu \& } \\
\text { Soylu, 2005) }\end{array}$ & $\begin{array}{l}\text { Toplama işleminin kuralı } \\
\text { çarpma işlemine } \\
\text { uyarlanmış, paylar } \\
\text { çarpılarak ortak paydada } \\
\text { yazılmıştır. }\end{array}$ & $\begin{array}{l}\text { 5. } \frac{4}{7} \times \frac{3}{7}=\text { ? yandaki işlemin sonucu } \\
\text { aşağıdakilerden hangisidir. } \\
\begin{array}{llll}\text { (2) } \frac{12}{7} & \text { b. } \frac{12}{49} & \text { c. } \frac{7}{17} & \text { d. } \frac{16}{49}\end{array}\end{array}$ \\
\hline $\begin{array}{l}\text { Örnek 6: 1/3x5/4 } \\
\text { işleminin sonucu } \\
\text { aşağ1dakilerden } \\
\text { hangisidir? (Soylu \& } \\
\text { Soylu, 2005) }\end{array}$ & $\begin{array}{l}\text { Toplama işleminin kuralı } \\
\text { çarpma } r \text { işlemine } \\
\text { uyarlanmış, } r \text { payda } \\
\text { eşitlemesi yapıldıktan } \\
\text { sonra paylar çarpılarak } \\
\text { ortak paydada yazılmıştır. }\end{array}$ & 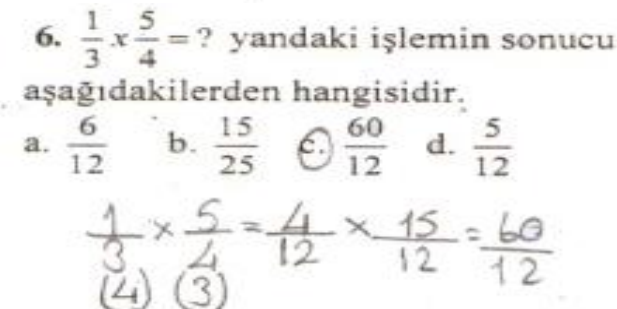 \\
\hline $\begin{array}{l}\text { Örnek 7-8: 2/3:3/2 } \\
\text { işleminin sonucu } \\
\text { aşağ1dakilerden } \\
\text { hangisidir? (Birgin \& } \\
\text { Gürbüz, 2009) }\end{array}$ & $\begin{array}{l}\text { İki rasyonel sayının } \\
\text { bölünmesi işleminde } \\
\text { ikinci rasyonel sayıyı ters } \\
\text { çevrilmeden çarpma } \\
\text { işlemi yapılmıştır. } \\
\text { İkinci rasyonel sayıyı ters } \\
\text { çevirip çarpmak yerine } \\
\text { birinci rasyonel sayıyı ters } \\
\text { çevirip çarpma işlemi } \\
\text { yapılmıştır }\end{array}$ & $\frac{2}{3}: \frac{3}{2}=\frac{3}{2} \cdot \frac{3}{2}=\frac{9}{4}$ \\
\hline
\end{tabular}

\section{Bulgular}

Öğretmenlere ilk olarak rasyonel sayılarda sıralama ile ilgili olan Örnek 1 ve Örnek 2 sırasıyla sunulmuştur. Öğretmenlerden bu güçlüğü incelemeleri ve sonrasında öğretimsel önerilerini sunmaları istenmiştir. Öğrenciler bu örneklerde kesrin pay ve paydasını kesirden bağımsız iki sayı gibi düşünerek sıralama yapmışlardır. Öğrenciler ya payın büyüklüğünü ya da paydanın büyüklüğünü dikkate almışlardır. Öğretmenlerin çözüm önerilerinin dört kategori altında toplandığı ortaya çıkmıştır. Tablo 3'te söz konusu kategoriler hakkında bilgiler sunulmuştur.

Tablo 3. Öğretmenlerin Örnek 1 ve Örnek 2' de Görülen Güçlüklere Sundukları Öneriler

\begin{tabular}{|c|c|}
\hline Kategoriler $(f)$ & Örnek ifadeler \\
\hline Farklı öğretim yöntemi (1) & $\begin{array}{l}\text { Gözde: Bu yüzden tekrar konuyu baştan farklı bir öğretim süreci ile anlatırım. } \\
\text { Onu ben slaytla ya da başka türlü anlattıysam başka bir öğretim yöntemini } \\
\text { düşünürüm. }\end{array}$ \\
\hline Model kullanma (4) & $\begin{array}{l}\text { Yücel: Yine modelleme yöntemini kullanırı. Bu kesirlerin her bir farklı } \\
\text { kesirler. Bunların hepsini ayn modelde göstermek lazım.... O şekilde giderilir } \\
\text { diye düşünüyorum. }\end{array}$ \\
\hline Kural hatırlatma (2) & $\begin{array}{l}\text { Ayşe: Üniversitede şöle görmüş̧ük. Yarıma tamamlama, tama tamamlama, } \\
\text { hangisi sıfıra yakın, } 1 / 2 \text { ye yakın, } 1 \text { e yakın. Sıralıyorsun kendi içinde olanları. } \\
\text { Ondan sonra tam stralamayı yapıyorduk. }\end{array}$ \\
\hline
\end{tabular}


Mahmut: Kesirlerin ilk önce basit mi birleşik mi. Yani kesir türlerini belirtmesi gerekiyor. Pozitif basit kesirlerin devamlı bileşik kesirlerden küçük olduğuna ve buna göre stralama yaparken buna dikkat etmesi gerektiğine vurgu yapardım. Öğrencilere siralama yaparken kullandığımız kuralları tekrar hatirlatırim.

Uygulamalı tekrar (1) Fatoş: Dediğim gibi bol pratik. ... denk kesir, eşit kesir kavramları ve geriye dönük eksiklerini tamamlamak gerekir.

Tablo 3 incelendiğinde öğretmenler çoğunlukla modeller kullanarak rasyonel sayılarda karşılaşılan bu sorunun üstesinden gelinebileceğini ifade etmişlerdir. İki öğretmen kuralları hatırlatmanın yararlı olacağını belirtmiştir. Bir öğretmen farklı öğretim yönteminin kullanılması gerektiğini dile getirirken bir öğretmen de bol tekrar yapmanın yararlı olacağını vurgulamıştır.

Öğretmenlere ikinci olarak, toplama işlemi ile ilgili olan Örnek 3 ve Örnek 4 sirasıyla sunulmuştur. Bu örneklerde öğrenciler iki rasyonel sayıyı toplarken payda eşitlemek yerine doğrudan payları toplayıp paya, paydaları toplayıp paydaya yazmışlardır. Öğretmenlerin bu güçlük için öne sürdükleri çözüm önerilerinin üç kategori altında toplandığı ortaya çıkmıştır. Tablo 4'te ortaya çıkan kategorilere yönelik bilgiler sunulmuştur.

Tablo 4. Öğretmenlerin Örnek 3 ve Örnek 4'te Görülen Güçlüklere Sundukları Öneriler

\begin{tabular}{ll}
\hline Kategoriler $(f)$ & Örnek ifadeler \\
\hline $\begin{array}{l}\text { Kural hatırlatma-tekrar } \\
\text { (5) }\end{array}$ & $\begin{array}{l}\text { Mahmut: Ben bu öğrencilerde ilk önce paydaların toplanamayacă̆ını } \\
\text { vurgularım. Öğgrenciye bir çalışma kâğıdı verilir. Öğrenciye paydaları eşit olan } \\
\text { 100-200 tane örnek olan. Bunu oğlum al eve götür ve hiçbir zaman paydalarıı } \\
\text { toplamayacaksın. Devamlı payların toplayarak bu şekilde kalıcı olur. Yani } \\
\text { öğrenci tekrar yapacak. }\end{array}$ \\
Model kullanma (3) & Yücel: Hocam ben bu öğrenciler için sürekli model üstünde anlatırım. \\
Farklı öğretim yöntemi (1) & $\begin{array}{l}\text { Gözde: Başka öğretim teknikleri düşünebilirim. Başka renkli renkli slaytlar, } \\
\text { renkli kartonlarla bunları öğretebilirim tekrardan. }\end{array}$ \\
\hline
\end{tabular}

Tablo 4 incelendiğinde öğretmenlerin çoğunlukla örneklerde görülen kavram yanılgılarının üstesinden gelmek için kural hatırlatma ve tekrar yapmayı önerdikleri ortaya çıkmıştır. Öğretmenlerin yarısı da bu zorlukları bertaraf etmek için modellerden yararlanılabileceğini belirtmiştir.

Öğretmenlere rasyonel sayılarda çarpma işlemi ile ilgili tespit edilen örnek öğrenme güçlükleri sunulmuştur. Öğretmenlere sunulan örneklerde, öğrenciler iki rasyonel sayıyı çarparken ortak payda altında sadece payları çarpmışlardır. Bu durum hem paydaları ortak payı farklı olan iki rasyonel sayıda hem de pay ve paydaları farklı iki kesrin çarpımında görülmüştür. Örnek 6 'da kesirler, toplama işlemi yapılacakmış gibi iki kesri ortak paydaya sahip olacakları şekilde genişletilmesine rağmen Örnek 5'te olduğu gibi sadece paylar çarpılmış ve ortak paydada yazılmıştır. Öğretmenlerin bu örneklerde görülen güçlükler için sundukları çözüm önerileri dört kategori altında toplanmış ve Tablo 5 'te sunulmuştur. 
Tablo 5. Öğretmenlerin Örnek 5 ve Örnek 6'da Görülen Güçlüklere Sundukları Öneriler

\begin{tabular}{|c|c|}
\hline Kategoriler $(f)$ & Örnek ifadeler \\
\hline $\begin{array}{l}\text { Kural hatırlatma-tekrar } \\
\text { (4) }\end{array}$ & $\begin{array}{l}\text { Mahmut: Öğrenciye kural devamlı hatırlatılmalıdır. Çarpma işleminde payda } \\
\text { eşitleme yoktur ve bu adım adım verilmelidir. }\end{array}$ \\
\hline İşlemi anlamlandırma (1) & $\begin{array}{l}\text { Gözde: Anlamlandırlması ile ilgili. Toplamayı, niye toplama yapıyoruz, } \\
\text { toplama sonucunda ne olur? Bu ikisi toplanır daha büyük bir sayı çıkar. } \\
\text { Çarpma işleminde pay ile pay çarpılır ama şu sayınının içinde şu kaç tane } \\
\text { vardır? Bölme işleminde aynı şekilde. Bu şekilde anlamlandırarak olabilir } \\
\text { ancak. }\end{array}$ \\
\hline Tartışma (1) & $\begin{array}{l}\text { Ayşe: Bu hataları arkadaşlarına gösteririz "Arkadaşınız nerde hata yaptı?" } \\
\text { arkadaşları vasıtası ile sınıfta tartışma ortamı yapmaya çalışırız. }\end{array}$ \\
\hline $\begin{array}{l}\text { Konu zamanlamasında } \\
\text { değişiklik (1) }\end{array}$ & $\begin{array}{l}\text { Fatoş: Toplama-çıkarmayı bir sene, çarpma-bölmeyi de başka bir sene verirsek } \\
\text { sanırım bu sorunu çözeriz. Ya da bir dönem sene olmasa bile, farklı dönemlerde } \\
\text { verirsek sanırım sıkıntı olmayacaktır. Ya da yaşanırsa da en aza inecektir. }\end{array}$ \\
\hline
\end{tabular}

Tablo 5'e göre, öğretmenlerin çoğunlukla bu güçlüklerin üstesinden gelebilmek için kurallara bağlı kalınarak sürekli hatırlatılmasını önerdikleri ortaya çıkmıştır. Bir öğretmen ilgili derslerin işleniş yöntemiyle ilgili bir öneri getirerek sınıfta tartışma ortamı oluşturulmasını önermiştir. Bir öğretmen de müfredatla ilgili bir eleştiri yaparak bu işlemlerin farklı dönemlerde öğretilmesi gerektiğine vurgu yapmıştır.

Öğretmenlere son olarak rasyonel sayılarda bölme işlemi ile ilgili olan Örnek 7 ve Örnek 8 sunulmuştur. Söz konusu örneklerde bölme işlemi için öğretilen kural yanlış uygulanmıştır. Örnek 7' de ikinci kesir ters çevrilmeden doğrudan çarpılmıştır. Örnek 8'de ise ikinci kesir ters çevrilmesi gerekirken birinci kesir ters çevrilip çarpılmıştır. Öğretmenlerin bu güçlüklere yönelik önerilerinin üç kategori altında toplandığı tespit edilmiştir. Tablo $\sigma^{\prime}$ da tespit edilen kategoriler hakkında bilgiler sunulmuştur.

Tablo 6. Öğretmenlerin Örnek 7 ve Örnek 8'de Görülen Güçlüklere Sundukları Öneriler

\begin{tabular}{|c|c|}
\hline Kategoriler $(f)$ & Örnek ifadeler \\
\hline Model kullanma (1) & $\begin{array}{l}\text { Gözde: Modelleme daha etkili oluyor diye düşünüyorum. Kuraldan ziyade } \\
\text { önce modelliyorum daha basit örneklerle, anlayabilecekleri örneklerle. Daha } \\
\text { sonra bu kural bu modellemeye uyuyor deyip diğer sorulara da genelliyoruz. }\end{array}$ \\
\hline $\begin{array}{l}\text { Kural hatırlatma-tekrar } \\
\text { (5) }\end{array}$ & $\begin{array}{l}\text { Ali: Bölme işlemi yaparken bu işlemin kuralının bu olduğu ve bunun dışına } \\
\text { çıkmaması gerektiğini söylerim. }\end{array}$ \\
\hline Farklı öğretim yöntemi (1) & $\begin{array}{l}\text { Fatoş: Çocuklar tekerlemeleri çok sever. Bunları tekerleme şekline getirebiliriz. } \\
\text { Oyun şekline, gerçi bunda oyun olmaz ama aklında kalıcılı̆̆ın sağlamak } \\
\text { önemli. Azıcık bir ritim katınca çocuk onu ezberleyebiliyor. Düz söyleyince } \\
\text { anlamıyor, ritim katıp biraz şekillendirince çocuğun aklında kesinlikle daha } \\
\text { kalıcı oluyor. }\end{array}$ \\
\hline
\end{tabular}

Tablo 6 incelendiğinde, öğretmenlerin rasyonel sayılar konusunda öğrencilerde bulunan bu tarz hataların üstesinden gelmek için çoğunlukla kural hatırlatma ve tekrar yapmayı önerdikleri ortaya çıkmıştır. Bir öğretmen modellerden yararlanılmasını, bir öğretmen ise 
alternatif yöntemler tercih ederek tekerleme, şarkı, oyun gibi aktivitelerle öğrencilerdeki kalıcılığı artırma yoluna gidilmesinin faydalı olacağını ifade etmiştir.

\section{Tartışma, Sonuç ve Öneriler}

Rasyonal sayıları sayı doğrultusunda gösterebilme ve sırayabilme hem rasyonel sayıların doğru algılanmasında yararlıdır hem de rasyonel sayıların doğru bir şekilde kavrandığının göstergelerinden biridir (Moss, 2002; Siebert \& Gaskin, 2006). Çalışmada kesirleri sıralama konusunda öğrencilerin yaşadıkları güçlüklerle ilgili olarak, öğretmenler çoğunlukla modeller kullanacaklarını ifade etmişlerdir. Öğretmenlerin yarısı düz anlatım yöntemi uygulamanın ve bol tekrar yapmanın bu güçlükle başa çıkmak için etkili bir yöntem olacağını belirtmişledir. Toplama işlemi ile ilgili güçlügün ortadan kaldırılması için öğretmenlerin çoğunlukla kural hatırlatmanın ve tekrar yapmanın güçlüğün üstesinden gelmek için yeterli olacağını belirtmişlerdir. Öğretmenlerin yarısı modeller kullanmanın bu güçlüğün üstesinden gelmede yararlı olacağını ifade etmiştir. Öğrencilerin rasyonel sayıları birbiri ile çarparken yaşadıkları güçlükle ilgili olarak, öğretmenler çoğunlukla kural hatırlatmanın yapılması gerektiğini ve müfredatta değişiklik yapılmasının yararlı olacağını belirtmiştir. İki öğretmen sınıfta yaratılacak tartışma ortamının ve anlamlı öğrenme için çalışmalar yapılmasının yerinde olacağını dile getirmiştir. Öğrencilerin bölme işleminde yaşadıkları güçlük için, öğretmenler çoğunlukla kural hatırlatma ve tekrar yapmakla bu güçlügün üstesinden gelinebileceğini belirtmiştir.

Çalışmadan elde edilen kategorilere bütüncül bir yaklaşımla bakıldığında, öğretmenlerin çoğunlukla sadece rasyonel sayılarda sıralama konusunda yaşanılan güçlükle ilgili yapılandırmacı felsefe ile ilişkilendirilebilecek yöntemler önerdikleri görülmüştür. Toplama, çarpma ve bölme konusunda yaşanılan güçlük için çoğunlukla kural hatırlatma-tekrar etme önerilmiştir. Model kullanma ve kural hatırlatma-tekrar etme kategorileri karşılaştırıldığında ise öğretmenlerin öncelikle kural hatırlatma-tekrar etmeyi önerdikleri, ikinci sırada model kullanmanın önerildiği ortaya çıkmıştır. Buna göre öğretmenlerin çoğunlukla yapılandırmacı yaklaşıma uygun olmayan, geleneksel anlayışa uygun öneriler sundukları söylenebilir. Çalışmadan elde edilen bu sonuç, matematik öğretmeni adayları ve matematik öğretmenleri ile yapılan araştırmalarla benzerlik göstermiştir (Can, 2019; Mumcu, 2017). Can (2019), matematik öğretmenlerinin rasyonel sayılar konusunda yaşanılan güçlüklere çözüm önerisi olarak model kullanımını ön planda tuttuklarını tespit etmiştir. Mumcu (2017), matematik öğretmeni adaylarının rasyonel sayılardaki kavram yanılgılarını engellemek amacıyla en çok model kullanma ve açılama yapma/soru sorma yöntemlerini tercih ettiklerini, yapılandırmacı yaklaşıma uygun strateji kullanan öğretmen adaylarının az sayıda olduğunu, açıklama yapma/soru sorma kategorisinde değerlendirilen öğretmen adaylarının tamamen geleneksel bir anlayış içinde olduklarını, kullanılan soruların ise öğrencilerin kavramları anlamaları ve aralarındaki ilişkileri keşfetmelerine yardımcı olacak nitelikte olmadığını tespit etmiştir.

Öğretmenlerin kural hatırlatmayı tercih etmelerinin sebebi, rasyonel sayılar konusuna yönelik kavramsal bir anlayışta olmamaları ve öğrencilerin bu konuda yaşadıkları güçlüklerin sebepleri konusunda yeterince bilgi sahibi olmamaları olabilir. Nitekim yapılan çalışmalarda matematik öğretmeni adayları ve öğretmenlerinin rasyonel sayılar konusunda kavramsal bilgilerin yetersiz olduğu (Can, 2019; Eroğlu, 2012; Gökkurt, Şahin \& Soylu, 2012; Iş1k, 2011; 
Karaağaç \& Köse, 2015; Lo \& Luo, 2012) ve öğrencilerin yaşadıkları güçlüklerin kaynağ1 konusunda yeterli bilgiye sahip olmadıkları tespit edilmiştir (Can, 2019; Eroğlu, 2012).

Kural hatırlatma, tekrar etme yaklaşımıyla yapılan öğretimlerin yansıması olarak öğrenciler formülleri, kuralları, prosedürleri ve terimleri kavramsal olarak anlamak, diğer işlem ve konularla ilişkisini kurmaktan ziyade formülleri ve algoritmaları ezberlemeye çabalamaktadırlar (Gökalp \& Sharma, 2004; Tirosh, 2000). Örneğin kesirlerde bölme işlemi için verilen "birinci kesri aynen al, ikinciyi ters çevir çarp" kuralının nereden geldiği öğrenciler (Durmuş, 2005), matematik öğretmen adayları (Işık, 2011) ve matematik öğretmenleri (Gökkurt, Şahin \& Soylu, 2012) tarafından bilinmemekte, ezberlenmek suretiyle sonraki kuşaklara aktarılmaktadır. Kılcan (2006) tarafından yapılan çalışmanın sonuçları bu görüşü desteklemiştir. Kılcan (2006), çalışmasına katılan ortaokul matematik öğretmenlerinin çoğunun kesirlerde bölme işlemi ile ilgili kavramsal bilgiye sahip olmadıklarını, kavramsal bilgiye sahip olmayan bu öğretmenlerin kesirlerde işlemleri kural vererek öğretme yolunu tercih ettiklerini tespit etmiştir. Bu çalışmada farklı öğretmenlik tecrübesine sahip öğretmenlerin yaptıkları çözüm önerilerinde dikkat çeken bir farklılaşmaya rastlanmamıştır. Buna göre kullanılan öğretim yöntemi seçiminde öğretmenlerin mesleki tecrübelerinin değil, konulara yönelik kavramsal bilgi düzeyinin etkili olduğu söylenebilir. Bu nedenle öğretmen yetiştiren kurumlarda öğretmen adaylarının kesir ve rasyonel sayılar konuları ve öğretimi ile ilgili kavramsal bilgilere sahip olması adına gerekli çalışmalar yapılabilir. Özellikle ilköğretim matematik öğretmenliği lisans programında kesir ve rasyonel sayılar konusunda temel kavramlar ve ilişkilerinin öğretiminin yapıldığı Matematiğin Temelleri 1 dersi ile bu konularının öğretimi ve öğrenci zorlukları konusunda öğretimin yapıldığı Sayıların Öğretimi dersine gerekli hassasiyetin gösterilmesi gerekmektedir. Matematik öğretmenlerine de kesirler ve rasyonel sayılar konusuna yönelik konu alanı ve pedagojik bilgilerini yeniden gözden geçirmelerine yönelik çalışmalar yapılabilir.

Öğretmenlerin en sık dile getirdiği ikinci öneri modellerin kullanılmasıdır. Matematik eğitimcileri de (Alacacı, 2014; Baki, 2014; Olkun \& Toluk Uçar, 2009) rasyonel sayıların öğretiminde somut malzeme, materyaller ve modellerden, resimsel malzeme ve görsel modellerden, geometrik şekillerden yararlanılmasını önermişlerdir. Model kullanma rasyonel sayılar konusunda yaşanılan güçlüklerin üstesinden gelmek için etkili bir yöntem olmasına karşın yapılan araştırmalar matematik öğretmeni adayları ve matematik öğretmenlerinin model geliştirme ve kullanma konusunda güçlük yaşadıklarını ortaya çıkarmıştır (Akgün ve diğerleri, 2013; Çelik \& Çiltaş, 2015; Mumcu, 2017). Bu nedenle öğretmenlerin derslerinde kullandıkları modeller gözlemlenerek model kullanma becerileri, kullanılan modellerin sıklığı, türü ve kalitesi araştırılabilir. Etkili bir rasyonel sayılar konusunun öğretiminde model kullanmanın yanı sıra, gerçek yaşam durumlarından yararlanılması, sözel problemlerin kullanılması, ezbere dayalı öğretim yerine sezgi kaynaklı kavramsal anlayışı sağlayacak öğrenme ortamlarının oluşturulması, rasyonel sayıların tüm anlamlarının ve temsillerin öğrencilere sunulması, rasyonel sayılarla ilgili temel kavramsal özellikler öğrencilerin zihinlerinde yerleşmeden kural ve işlemlere geçilmemesi de sıklıkla önerilmiştir (Albayrak, 2010; Demirdöğen ve Kaçar, 2010; Doğan-Temur, 2011; Durmuş, 2005; Güç, 2017; Işık, 2011; İpek vd., 2005; Tirosh, 2002; Toluk, 2002; Tutak, 2019; Van de Walle ve diğerleri, 2014). Bu çalışmada öğretmenlerin daha çok model kullanma yöntemine odaklandıkları ve yukarıda önerilen durumlara çok az değindikleri ortaya çıkmıştır. Öğretmenlerin rasyonel sayılar konusunun öğretiminde model kullanımı ile birlikte yukarıda ifade edilen öğretimsel önerileri de dikkate alarak öğretim yapmaları önerilebilir. 
Bu çalışma, rasyonel sayılar konusunda öğrencilerde yaygın olarak görülen dört farklı tarzda öğrenme güçlügü kullanılarak altı ortaokul matematik öğretmeni ile yürütülmüştür. Rasyonel sayılar konusunda yaşanılan farklı öğrenme güçlükleri ve farklı araştırma grupları kullanılarak çalışmalar yapılabilir. Öğretmenlere rasyonel sayılar konusu gibi öğrencilerin anlamakta zorlandığ 1 konularda kullanılabilecek öğretim yöntemleri konusunda uygulamalı eğitimler verilebilir. Ayrıca öğretmenlerin rasyonel sayılar konusundaki mesleki gelişimlerine katkı sağlaması için bu konuya dönük hizmet içi eğitim seminerleri düzenlenebilir.

\section{Kaynakça}

Akgün, L., Çiltaş, A., Deniz, D., Çiftçi, Z., \& Işık A. (2013). İlköğretim matematik öğretmenlerinin matematiksel modelleme ile ilgili farkındalıkları. Adryaman Üniversitesi Sosyal Bilimler Enstitüsü Dergisi, 12(6), 1-34.

Alacaci, C. (2009). Öğrencilerin kesirler konusundaki kavram yanılgıları. E. Bingölbali ve M. F. Özmantar (Ed.), İlköğretimde karşılaşılan matematiksel zorluklar ve çözüm önerileri (1. Baskı). Ankara: Pegem Akademi Yayınları.

Albayrak, M. (2010). Eğitim fakülteleri ve sınıföğretmenleri için ilköğretimde matematik ve öğretimiI (3. Bask1). Erzurum: Mega Ofset Matbaacilık.

Altun, M. (2013). Ĕ̆itim fakülteleri ve sını ö̆gretmenleri için matematik öğretimi. Bursa: Aktuel Yayincilik.

Balc1, M. (2008). Genel matematik 1. Ankara: Balcı Yayınları.

Baykul, Y. (2014). Ortaokulda matematik öğretimi (5-8 sinıflar) (2. Baskı). Ankara: Pegem Yayıncilik.

Behr, M. J., Harel, G., Post, T. R., \& Lesh, R. (1992). Rational number, ratio, and proportion. In D. A. Grouws (Ed.), Handbook of research on mathematics teaching and learning (pp. 296333). New York: Macmillan.

Bektaş, M., Kahraman, S., \& Temel, Y. (2018). Ortaokul ve imam hatip ortaokulu matematik ders kitabı 6. Ankara: Milli Eğitim Bakanlığı Yayınları.

Bezuk, N. S., \& Bieck, M. (1993). Current research on rational numbers and common fractions: summary and implications for teachers. D. T. Owens (Ed.), In Research ideas for the classroom middle grades mathematics (pp. 118 - 136). New York: MacMillan.

Biber, A. Ç., Tuna, A., \& Aktaş, O. (2013). Öğrencilerin kesirler konusundaki kavram yanılgıları ve bu yanılgıların kesir problemleri çözümlerine etkisi. Trakya Üniversitesi Ĕ̆itim Fakültesi Dergisi, 3( 2), 152-162.

Birgin, O., \& Gürbüz, R. (2009). İlköğretim II. kademe öğrencilerinin rasyonel sayılar konusundaki işlemsel ve kavramsal bilgi düzeylerinin incelenmesi. Uludă̆ Üniversitesi Eğitim Fakültesi Dergisi 22(2), 529-550.

Böge, H., \& Akıllı, R. (2018). Ortaokul ve imam hatip ortaokulu matematik 8 ders kitabı. Ankara: Milli Eğitim Bakanlığı Yayınları.

Brown, G., \& Quinn, R. J. (2007). Fraction proficiency and success in algebra: What does research say? Australian Mathematics Teacher, 63(3), 23-30. 
Can, H.N. (2019). Ortaokul matematik öğretmenlerinin kesirlerde işlemler konusu ile ilgili pedagojik alan bilgilerinin öğrenci zorlukları ve kavram yanılgıları bileşeninde incelenmesi (Yayınlanmamış yüksek lisans tezi). Marmara Üniversitesi, İstanbul.

Cırıtçı, H., Gönen, İ., Kavas, D., Özarslan, M., Pekcan, N., \& Şahin, M. (2018). Ortaokul ve imam hatip ortaokulu matematik ders kitabı 5. İstanbul: Bilnet Matbaacılık.

Çelik, B. (2006). Temel matematik. Ankara: Nobel Yayınları.

Çelik, B., \& Çiltaş, A. (2016). Beşinci sınıf kesirler konusunun öğretim sürecinin matematiksel modeller açısından incelenmesi. Bayburt Ĕ̆itim Fakültesi Dergisi, 10 (1), 180-204.

De Castro, B. (2008). Cognitive models: the missing link to learning fraction multiplication and division. Asia Pacific Education Review, 9(2), 101-112.

Demirdöğen, N., \& Kaçar, A. (2010). İlköğretim 6. sınıfta kesir kavramının öğretiminde gerçekçi matematik eğitimi yaklaşımının öğrenci başarısına etkisi. Erzincan Eğitim Fakültesi Dergisi, 12-1.

Doğan-Temur, Ö. (2011). Dördüncü ve beşinci sınıf öğretmenlerinin kesir öğretimine ilişkin görüşleri: fenomenografik araştırma. Dumlupınar Üniversitesi Sosyal Bilimler Dergisi, 29, 203212.

Durmuş, S. (2005). Rasyonel sayılarda bölme işlemini ilköğretim öğrencilerin algılayışları. Sakarya Üniversitesi Ĕ̆itim Fakültesi Dergisi. 9, 97-109.

Erdem, E. (2016). Prospective middle school mathematics teachers' (PMTs) content knowledge about concepts 'fraction' and 'rational number'. Journal of Education and Training Studies, 4(6), 80-92.

Erenkuş, M.A., \& Eren-Savaşkan, D. (2018). Ortaokul ve imam hatip ortaokulu 7. sınıf matematik ders kitabı. Ankara: KOZA Yayın AŞ.

Ersoy, Y. \& Erbaş, K. (2005). Kassel projesi cebir testinde bir grup türk öğrencinin genel başarısı ve öğrenme güçlükleri. İlköğretim Online, 4(1),18-39.

Gokalp, N. D. and Sharma, M. D. (2010). A study on addition and subtraction of fractions: The use o Pirie and Kieren model and hands- on activities, Procedia Social and Behavioral Sciences 2(2010), 5168- 5171

Gökkurt, B., Soylu, Y., \& Demir Ö. (2015). Ortaokul matematik öğretmenlerinin kesirlerin öğretimine yönelik görüşlerinin incelenmesi. Necatibey Eğitim Fakültesi Elektronik Fen ve Matematik Ĕ̈itimi Dergisi, 9(2), 230-251.

Gökkurt, B., Şahin, Ö., \& Soylu, Y. (2012). Matematik öğretmenlerinin matematiksel alan bilgileri ile pedagojik alan bilgileri arasındaki ilişkinin incelenmesi. The Journal of Academic Social Science Studies, 5(8), 997-1012.

Güç, F. (2017). Rasyonel sayılar ve rasyonel sayılarda işlemler konusunda ters-yüz sınıfuygulamasının etkileri (Yayınlanmamış yüksek lisans tezi). Amasya Üniversitesi, Amasya.

Haser, Ç. ve Ubuz, B. (2002). Kesirlerde kavramsal ve işlemsel performans. Ĕ̆itim ve Bilim, 27(126), 53-61.

Işık, C. (2011). İlköğretim matematik öğretmeni adaylarının kesirlerde çarpma ve bölmeye yönelik kurdukları problemlerin kavramsal analizi. Hacettepe Üniversitesi Eğitim Fakültesi Dergisi, 41, 231-243.

Işık, C., \& Kar, T. (2012). 7. sınıf öğrencilerinin kesirlerde toplama işlemine kurdukları problemlerin analizi. İlköğretim Online, 11(4), 1021-1035. 
İpek, A. S., Işık, C., \& Albayrak, M. (2005). Sınıf öğretmeni adaylarının kesir işlemleri konusundaki kavramsal performansları. Kazım Karabekir Eğitim Fakültesi Dergisi, 1, 537-547.

Kaleli Yılmaz, G. (2015). Durum çalışması. Mustafa Metin (Ed.). Kuramdan uygulamaya eğitimde bilimsel araştırma yöntemleri içinde (s. 261-285). Ankara: Pegem Akademi.

Karaağaç, M. K. ve Köse, L. (2015). Öğretmen ve öğretmen adaylarının öğrencilerin kesirler konusundaki kavram yanılgıları ile ilgili bilgilerinin incelenmesi. Sakarya Üniversitesi Ĕ̈itim Fakültesi Dergisi,30, 72-92.

Kılcan, S.A. (2006). Illköğretim Matematik Öğretmenlerinin Kesirlerle Bölmeye İlişkin Kavramsal Bilgi Düzeyleri. Yüksek Lisans Tezi, Bolu Abant İzzet Baysal Üniversitesi, Bolu.

Kocaoğlu, T., \& Yenilmez, K. (2010). Beşinci sınıf öğrencilerinin kesir problemlerinde yaptıkları hatalar ve kavram yanılgıları. Dicle Üniversitesi Ziya Gökalp Ĕgitim Fakültesi Dergisi, 14, 71-85.

Lamon, S. J. (2007). Rational numbers and proportional reasoning: Toward a theoretical framework for research. In F. K. Lester (Ed.), Second handbook of research on mathematics teaching and learning (pp. 629-667). Charlotte, NC: Information Age Publishing.

Lo, J.J., \& Luo, F. (2012). Prospective elementary teachers' knowledge of fraction division. J Math Teacher Educ, 15, 481-500.

Macit, E., \& Nacar, S. (2019). İlköğretim matematik öğretmenliği öğrencilerinin rasyonel sayı ve kesir kavram imajları. İnönü Üniversitesi Ĕ̆itim Bilimleri Enstitüsü Dergisi, 6(11), 50-62.

Merriam, S.B. (2013). Nitel araştırma desen ve uygulama için bir rehber. (Çev. Ed. S. Turan). Ankara: Nobel Akademik Yayıncilık.

Miles, B.M., \& Huberman, M.A. (1994). Qualitative data analysis. London: Sage Publication.

Milli Eğitim Bakanlığı [MEB] (2018). Matematik dersi öğretim programı (İlkokul ve Ortaokul 1, 2, 3, 4, 5, 6, 7 ve 8. Sinıflar). Ankara: Talim Terbiye Kurulu Başkanlığı.

Mok, I., Cai, J., \& Fong-Fung, A. (2008). Missing learning opportunities in classroom instruction: evidence from an analysis of a well-structured lesson on comparing fractions. The Mathematics Educator, 11(1-2), 111-126.

Moss J. (2002). Percents and proportion at the center: Altering the teaching sequence for rational number. Making sense of fractions, ratios and proportions. National Council of Teachers of Mathematics, Reston Virginia.

$\mathrm{Ni}$, Y. J. (2001). Semantic domains of rational numbers and the acquisition of fraction equivalence. Contemporary Educational Psychology, 26, 400-417.

Niven, I. (1961). Numbers: rational and irrational (Vol. 1). New York: Random House.

Olive, J. (1999). From fractions to rational numbers of arithmetic: a reorganization hypothesis. Mathematical Thinking and Learning, 1(4), 279-314.

Olkun, S., \& Toluk Uçar, Z. (2009). İlköğretimde etkinlik temelli matematik öğretimi. Ankara: Anı Yayıncilik.

Orhun, N. (2007). Kesir işlemlerinde formal aritmetik ve görselleştirme arasındaki bilişsel boşluk. İnönü Üniversitesi Eğitim Fakültesi Dergisi, 8(14), 99-111.

Pantziara, M., \& Philippou, G. (2011). Levels of students' “conception" of fractions. Educational Studies in Mathematics, 79 (1), 61-83.

Pesen, C. (2008). Kesirlerin sayı doğrusu üzerindeki gösteriminde öğrencilerin öğrenme güçlükleri ve kavram yanılgıları. İnönü Üniversitesi Eğitim Fakültesi Dergisi, 9(15), 157-168. 
Prediger, S. (2011). Why Johnny can't apply multiplication? Revisiting the choice of operations with fractions. International Electronic Journal of Mathematics Education, 6(2), 65-88.

Shulman, L. S. (1986). Those who understand: Knowledge growth in teaching. Educational Researcher, 15 (2), 4-14.

Siebert, D., \& Gaskin, N. (2006). Creating, Naming, and Justifying Fractions. Teaching Children Mathematics, 12(8), 394-400.

Son, J. W. (2011). A global look at math instruction. Teaching Children Mathematics, 17(6), 360368.

Soylu, Y., \& Soylu, C. (2005). İlköğretim beşinci sınıf öğrencilerinin kesirler konusundaki öğrenme güçlükleri: kesirlerde sıralama, toplama, çıkarma, çarpma ve kesirlerle ilgili problemler. Erzincan Ĕ̆itim Fakültesi Dergisi, 7(2), 101-117.

Stafylidou, S., \& Vosniadou, S. (2004). The development of students' understanding of the numerical value of fractions. Learning and Instruction, 14, 503-518.

Şiap, İ., \& Duru, A. (2004). Kesirlerde geometriksel modelleri kullanabilme becerisi. Kastamonu Ĕ̈itim Dergisi, 12 (1), 89-96.

Tirosh, D. (2000). Enhancing prospective teachers' knowledge of children's conceptions: the case of division of fractions. Journal for Research in Mathematics Education, 31(1), 5-25.

Toluk, Z. (2002). İlkokul Öğrencilerinin Bölme İşlemi ve Rasyonel Sayıları İlişkilendirme Süreçleri. Boğaziçi Üniversitesi Ĕ̆itim Fakültesi Dergisi, 19(2), 81-103.

Tutak, A.M. (2019). Kesirler konusunun görsel materyal ile öğreniminin ilkokul öğrencilerinin matematik başarısına ve tutumuna etkisi (Yayınlamamış yüksek lisans tezi). Fırat Üniversitesi, Elazı̆

Usiskin, Z. P. (1979). The future of fractions. The Arithmetic Teacher, 26(5), 18-20.

Ünlü, M., \& Ertekin, E. (2012). Why do pre-service teachers pose multiplication problems instead of division problems in fractions? Procedia - Social and Behavioral Sciences, 46, 490494.

Vamvakoussi, X., \& Vosniadou, S. (2010). How many decimals are there between two fractions? Aspects of secondary school students' understanding of rational numbers and their notation. Cognition and instruction, 28(2), 181-209.

Van de Walle, J. A., Karp, K. S., \& Bay-Williams, J. W. (2013). İlkokul ve ortaokul matematiği gelişimsel yaklaşımla öğretim (7. Baskı).(Çev. S. Durmuş). Ankara: Nobel Yayınları.

Vanhille, L.S., \& Baroody, A.J. (2002). Fraction instruction that fosters multiplicative reasoning. making sense of fractions, ratios and proportions. National Council of Theachers of Mathematics, Restorn Virginia.

Yanık, H.B. (2013). Rasyonel sayılar. İ.Ö. Zembat vd. (Ed.). Tanımları ve tarihsel gelişimleriyle matematiksel kavramlar içinde (s. 95-110). Ankara: Pegem Akademi.

Yeniterzi, B. (2009). 7. simıfta uygulanan rasyonel sayılarla ilgili etkinliklerin matematik kazanımların elde etmeye etkisi (Yayınlanmamış yüksek lisans tezi). Selçuk Üniversitesi, Konya.

Yıldırım, A., \& Şimşek, H. (2013). Sosyal bilimlerde nitel araştırma yöntemleri (9. Baskı). Ankara: Seçkin yayınevi.

Wu, H. H. (2001). How to prepare students for algebra. American Educator, 25(2), 10-17.

Zengin, S. (2013). Rasyonel sayıların öğretiminde karşılaşılan kavram yanılgıları ve hataların tespiti (Yayınlanmamış yüksek lisans tezi). Atatürk Üniversitesi, Erzurum. 